\title{
First report of leaf and twig blight of Indian hawthorn (Rhaphiolepis indica) caused by Neofusicoccum parvum in Italy
}

\author{
Giorgio Gusella $^{1}$ (D) Dalia Aiello ${ }^{1} \cdot$ Giancarlo Polizzi $^{1}$ \\ Received: 28 June 2019 / Accepted: 5 September 2019/Published online: 15 October 2019 \\ (C) Società Italiana di Patologia Vegetale (S.I.Pa.V.) 2019
}

Keywords Botryosphaeriaceae $\cdot$ Leaf Blight $\cdot$ Neofusicoccum parvum $\cdot$ Rhaphiolepis indica

During the winter of 2018 symptoms of leaf and twig blight were observed on about $15 \%$ of 75004 -year-old potted plants of Indian hawthorn [Rhaphiolepis indica (L.) Lindl.] grown in a commercial nursery in Catania province, Italy.

Necrosis was found in the petioles, moving upward through the mid rib and blade, showing brownish V-shape lesion at the bottom of the leaves and leading to a complete blight of the twigs. Under the bark, discolored tissue was found. Diseased tissues were surface disinfected for $1 \mathrm{~min}$ in $1.5 \%$ sodium hypochlorite solution, rinsed in sterile water, placed on PDA amended with $100 \mathrm{mg} / \mathrm{l}$ of streptomycin sulfate, and then incubated at $25^{\circ} \mathrm{C}$ for seven days. A fungus like Neofusicoccum sp. was consistently isolated. ITS region of rDNA and part of tefl gene were amplified using ITS5, ITS4 and EF1-728F, EF1-986R primers, respectively. The sequence data were deposited in GenBank. BLAST analysis identified the fungus as Neofusicoccum parvum (Pennycook \& Samuels) Crous, Slippers \& A.J.L. Phillips. The obtained ITS sequences (GenBank accession Nos. MN128645; MN128646) of the isolates CBS 145794, CBS 145795 showed $99.65 \%$ and $99.83 \%$ identity with the tester isolate (KJ657701) respectively, and tef sequences (MN175951; MN175952) showed $100 \%$ and $98.97 \%$ (KJ126847). The isolates have been registered in the CBS Westerdijk Fungal
Biodiversity Institute collection (Utrecht). Pathogenicity tests were conducted inoculating 10 twigs with a mycelial plug. Control consisted of sterile PDA plugs. Plants were moved into a growth chamber at $25{ }^{\circ} \mathrm{C} \pm 1{ }^{\circ} \mathrm{C}$. The same symptoms observed in field appeared on $90 \%$ of the inoculated twigs after 10 days and complete twigs blight of the apical part of the plant after 17 days. Re-isolations completed Koch's postulates. This fungus is spreading in Sicily on different important crops (Guarnaccia et al. 2016; Ismail et al. 2013) but for our knowledge, this is the first report of leaf and twig blight caused by N. parvum on Indian hawthorn.

\section{References}

Guarnaccia V, Vitale A, Cirvilleri G, Aiello D, Susca A, Epifani F, Perrone G, Polizzi G (2016) Characterisation and pathogenicity of fungal species associated with branch cankers and stem-end rot of avocado in Italy. Eur J Plant Pathol 146(4):963-976

Ismail AM, Cirvilleri G, Lombard L, Crous PW, Groenewald JZ, Polizzi G (2013) Characterisation of Neofusicoccum species causing mango dieback in Italy. J Plant Pathol 95(3):549-557

Publisher's note Springer Nature remains neutral with regard to jurisdictional claims in published maps and institutional affiliations.
Giorgio Gusella

giorgio.gusella@studium.unict.it

1 Dipartimento di Agricoltura, Alimentazione e Ambiente, sezione Patologia Vegetale, University of Catania, Via S. Sofia 100, 95123 Catania, Italy 